\title{
CHANGES IN THE ANTIOXIDATIVE SYSTEM OF THE RED MASON BEE (OSMIA RUFA) (HYMENOPTERA: MEGACHILIDAE) INDUCED BY ARTIFICIALLY ELONGATED DIAPAUSE
}

\author{
Kamila Dmochowska ${ }^{1}$, Karol Giejdasz ${ }^{2}$, \\ Monika Fliszkiewicz ${ }^{2}$, Krystyna Źóltowska ${ }^{1}$ \\ ${ }^{1}$ Department of Biochemistry, Faculty of Biology, \\ University of Warmia and Mazury, 1A Oczapowskiego Street, 10-719 Olsztyn, Poland \\ ${ }^{2}$ Department of Apidology, Institute of Zoology, Poznań \\ University of Life Sciences, 71C Wojska Polskiego Street, 60-625 Poznań, Poland \\ e-mail: kamila.dmochowska@uwm.edu.pl
}

Received 19 December 2011; accepted 24 April 2012

$\mathrm{S}$ u m m a r y

Osmia rufa as a polylectic insect is used in the pollination of numerous plants. The usefulness of this insect for plant breeders is considerably limited because of the short flight periods of the insects in the natural environment. In order to break this limitation, the wintering period of the insects in cocoons is elongated. The temperature is maintained at $4^{\circ} \mathrm{C}$ up to the time of plant blooming. This treatment does shortens the lifetime of the insects which may be the result of oxidative stress. Such results led to the examination of the selected components of antioxidative system. These components are: total antioxidative status, content of glutathione and activity of peroxidase and glutathione S-transferase in O. rufa emerged in spring, according to their biological clock, and emerged in summer - after elongated diapause. It was observed that diapause elongation unprofitably influenced the antioxidative system of a bee. A statistically significant decrease in total antioxidative status, and activity of both antioixidative enzymes - peroxidase and glutathione S-transferase, was noted. The changes in the glutathione level in turn, were insignificant. In our opinion, the lower efficiency of antioxidative systems of the red mason bee emerged in summer, may limit their response ability to endo- and exogenous factors influencing oxidative stress. The results of our study are the first publication concerning an antioxidative system in mason bees.

Keywords: antioxidative system, solitary bees, red mason bee, Osmia rufa, diapause.

\section{INTRODUCTION}

Mason bees are more and more widely used as cultivated plant pollinators. The factor limiting their utilisation on plantations in nature is the bees relatively short insect flight period. In North-Central Europe, the red mason bee pollinates plants from the second half of April up to the third decade of June. Mason bees winter in a cocoon as imago. Their diapause may be elongated artificially by maintaining the insects at a temperature of $4^{\circ} \mathrm{C}$ or a low temperature $\left(0^{\circ} \mathrm{C}\right)$ (Bosch and Kemp, 2003, 2004). Therefore, the range of plants visited by $O$. rufa is increased with plants blooming beyond the term of bees flights in natural conditions (Wilkaniec, 1991). Such actions allow the utilisation of the bees for pollinating plants blooming in spring and summer. Artificial elongation of wintering in mason bees also has negative consequences. Maintenance of $O$. rufa at a temperature of $4^{\circ} \mathrm{C}$ prevents emerging of individuals from cocoons, but does not entirely inhibit metabolic changes (unpubl. data). At this time, the consumption of reserve substances stored in the insect's organism is higher than during diapause (Bosh and Kemp, 2003, 2004; S golastra et al., 2010; unpubl. data). It was observed 
that elongated diapause decreases survival rate and shortens the mean lifetime of active bees (Giejdasz and Wilkaniec, 1998).

Red mason bees, like all aerobes, generate reactive oxygen species (ROS) during normal metabolic changes. When neutralized, they may cause damage on each of the levels of the organism's organisation. For that reason, the organisms formed specific antioxidative and reconstructive systems (Bartosz, 2003). During diapause, the insects do not feed, virtually do not move, and have a low respiration rate (Storey, 1990). Such a state limits, but does not entirely stop the formation of ROS, which may cause damage of all the most important cell components: nucleic acids, proteins and lipids. Whiteley et al. (1992) noted lipids peroxidation during liver storage at $-70^{\circ} \mathrm{C}$. So, even such a low temperature does not protect against damage caused by ROS.

The above statement may be particularly important as concerns the red mason bees, since during diapause the metabolism is mainly based on lipid transformations. Intense synthesis of vitellogenin in the adipose body and their transfer to reproductive cells is observed in that period (Maeta and Kurihara, 1971). Wasielewski et al. (2011) demonstrated, that an increase in the size and number of oocytes of red mason bees take place during the entire overwintering period. In order to protect the pool of generative cells, $O$. rufa needs to have strong antioxidative systems protecting the oocytes against ROS damages. This is especially true in the artificial wintering elongation. In bees of Osmia genus, elongation is connected to an increase in respiratory quotient (Sgolastra et al., 2010), and such a state means higher ROS generation.

Elongation of diapause may thus lead to oxidative stress occurrence. That is a very unprofitable state for an organism. In this state, ROS production exceeds the possibilities of their inactivation and limits reconstructive abilities of damaged cellular structures. Such a state may be another reason, (other than when reserve substances are exhausted), for a lower survivability percentage and the shorter lifetime of red mason bees with artificially elongated diapause period.

The aims of our study were to present an analysis of the elements of the antioxidative system of red mason bees and to present the influence of stress factor on that system. The efficiency of the antioxidative system of imago of the O. rufa female at the beginning of the natural flight period and after the period of artificially elongated diapause were determined. For that purpose, the total antioxidative status (TAS), glutathione level (GSH) and activity of peroxidase (POX) and glutathione S-transferase (GST) in both groups of bees were examined. This is the first study in the world concerning the antioxidative system of mason bees.

\section{MATERIALS AND METHODS}

The experimental material were imago of red mason bees Osmia rufa L. obtained from the rearing population situated at the Swadzim Biological Station of the Department of Apidology, Poznań University of Life Sciences (Poznań, Poland). The $O$. rufa cocoons and the artificial nests were placed in nesting shelters at the beginning of April. During the nesting period (from April to June 2009), the nest tubes were occupied by $O$. rufa females. The tubes were left in the nesting site till February and then were transferred to a laboratory. In the laboratory, the nest tubes were dismantled and the adult bees in cocoons were removed from nest cells. The diapausing bees and the bees with prolonged wintering period were kept in a cooler $\left(4^{\circ} \mathrm{C}\right)$ until the time of artificial incubation.

On April the $5^{\text {th }}$ and July the $2^{\text {nd }}$ cocoons of O. rufa were places in an incubator at $25^{\circ} \mathrm{C}$. The newly emerged bees were weighed and immediately placed in eppendorf tubes and anaesthetized with liquid nitrogen. Until analyses, the material was stored at $-71^{\circ} \mathrm{C}$. From the population of red mason bees emerged in April and in 
July, 40 females were randomly selected. Next, these females were divided into 20 samples (each of 2 individuals). Samples were homogenized in an ice bath for 2 minutes with $0.9 \% \mathrm{NaCl}$ at a $1: 10(\mathrm{w} / \mathrm{v})$ ratio. The homogenate was centrifuged at $4^{\circ} \mathrm{C}$ for 15 minutes at $15000 \times \mathrm{g}$. Supernatant was carefully collected for further analyses. Total antioxidant status, glutathione level, the activities of enzymes -glutathione S-transferase and peroxidise as well as protein content were assayed in the bee extracts.

Total antioxidant status was assayed according to Re etal.(1999), the glutathione level by the Ellman (1959) method. The activity of proxidase was determined according to Chance and Maehly (1955), glutathione S-transferase by the method of Rice-Evans et al. (1991). The proteins were assayed spectrophotometrically $\left(\mathrm{A}_{280}\right)$ using NanoDrop ND - 1000 apparatus (UV - Vis Spectrophotometer, USA).

The obtained results were statistically analyzed using the U-Mann-Whitney test in Statistica 9 software (StatSoft Inc., Poland) at the significance level $\alpha<0.05$.

\section{RESULTS}

Red mason bees emerged in April weighed from 77.4 to $134.2 \mathrm{mg}$, and the ones emerged in July weighed from 52.3 to $122.8 \mathrm{mg}$. In this study, we have reported total antioxidant status, glutathione level as well as the peroxidase activity and S-glutathione transferase of newly emerged $O$. rufa (Tab. 1). The results proved that artificially prolonged diapause had a harmful effects on the antioxidative system of red mason bees. The activity of peroxidase and S-glutathione transferase and TAS were significantly lower in $O$. rufa emerged in July than in April. Only the glutathione level hardly changed.

\section{DISCUSSION}

The health status and individual organism homeostasis maintenance are conditioned by the proper state of the antioxidative system, which allows successful scavenging of free radicals and reconstruction of damages of important for life molecules caused by them. Red mason bees belong to the group of insects, for which biochemistry and physiology have not yet been fully recognised.

Based on the results of the presented paper, it may be concluded, that red mason bees possess a very efficient antioxidative system. Their system is characterised by a high ability for free radical scavenging (TAS) which is three fold higher when compared to Apis mellifera worker bees (Farjan, 2008; Lipiński et al., 2008). Also, the glutathione level - low-molecular antioxidant, was four fold higher in mason bees than in freshly emerged honeybee workers (Farjan, 2008).

In insects, glutathione S-transferase is the key detoxification enzyme, which also determines oxidative stress resistance. This especially concerns stress caused by toxic compounds present in an environment, like heavy

Comparison of selected antioxidant parameters

of $O$. rufa females emerged in spring and in summer

\begin{tabular}{|c|c|c|c||}
\hline Antioxidant parameters & $\begin{array}{c}\text { Spring emerged } \\
\text { (mean } \pm \text { SD, } \\
\text { range) }\end{array}$ & $\begin{array}{c}\text { Summer emerged } \\
\text { (mean } \pm \text { SD, } \\
\text { range) }\end{array}$ & $\begin{array}{c}\text { U-Mann-Whitney } \\
\text { test results }\end{array}$ \\
\hline TAS & $\begin{array}{c}320.99 \pm 20.66 \\
(290.34-361.81)\end{array}$ & $\begin{array}{c}\mathbf{2 9 1 . 6 6 \pm 2 1 . 8 3} \\
(262.92-336.62)\end{array}$ & $\mathrm{U}=73.00$ \\
(Trolox equivalents/100 mg tissue) & $0.0006^{\mathrm{a}}$ \\
\hline GSH & $16.85 \pm 1.84$ & $17.62 \pm 1.88$ & $\mathrm{U}=156.00$ \\
(mg/100 mg tissue) & $(14.54-19.98)$ & $(14.75-20.59)$ & $\mathrm{p}=0.2393$ \\
\hline POX & $\mathbf{0 . 6 8 9} \pm 0.076$ & $\mathbf{0 . 5 7 0 \pm 0 . 0 9 6}$ & $\mathrm{U}=65.00$ \\
(U/mg proteins) & $(0.566-0.802)$ & $(0.452-0.727)$ & $\mathrm{p}=0.00027^{\mathrm{a}}$ \\
\hline GST & $3.62 \pm 0.48$ & $3.23 \pm 0.66$ & $\mathrm{U}=133.00$ \\
(U/mg proteins) & $(3.06-4.49)$ & $(2.25-4.38)$ & $\mathrm{p}=0.0286^{\mathrm{a}}$ \\
\hline
\end{tabular}

a - significant differences between means 
metals (Kafel et al., 2003), insecticides (Hayaoka and Dauterman, 1982), allochemical compounds (Yu, 1992) and other xenobiotics (Després et al., 2007). High GST activity is connected to the expression of metabolic resistance to insecticides (Clark, 1990). The mason bee is characterised by high GST activity, three fold higher than activity in females of the other solitary bee - Megachile rotundata (Fröhlich et al., 1989). It is interesting that $M$. rotundata males were characterized by considerably higher GST activity when compared to females. Probably, similar sex related differences can be observed in O. rufa. In Apis mellifera, GST activity was higher in drones than in queens (Weirich et al., 2002; Collins et al., 2004). Glutathione S-transferase may play a role in the protection of sperm from oxidation in the spermatheca of honey bee queens (Collins et al., 2004). Although the activity of GST in freshly emerged mason bees was lower than in workers of A. mellifera (Farjan, 2008), it was much higher than in Ostrinia nubialis (Jovanovic-Galovic et al., 2004).

In the case of peroxidase, O. rufa was characterized by POX activity which was as much as one rank higher when compared to A. mellifera (Farjan, 2008; Lipiński et al., 2008). Interspecies differences in antioxidative enzymes activity are also observed in other insects. For example, species belonging to the same family: Papilio polyxenes and $P$. cresphontes also differ in their GST activity (Lee and Barenbaum, 1992).

The comparison of $O$. rufa with A. mellifera is interesting due to their affiliation to one superfamily Apoidea with the same haplodiploid genetic systems, but different social behaviors. Oakeshott et al. (2010) noted the lower number of genes encoding antioxidative enzymes in honey bees when compared to other insects. For example, Drosophila melanogaster has as much as 37 cytosolic GST isoforms, Bombyx mori 23, and A. mellifera only 8 . The lower number of genes of enzymes connected to xenobiotics metabolism is supposed to be a consequence of honey bee social behavior (Oakeshott et al., 2010). According to this hypothesis, solitary insects should posses a more efficient antioxidative system when compared to social insects. The higher TAS and peroxidase activity in mason bees when compared to A. mellifera (Farjan, 2008; Lipiński et al., 2008), is consistent with that hypothesis.

The level of GST activity is changing during onthogenesis in insects (Feng et al., 2001; Papadopoulos et al., 2004; Farjan, 2008). In most insects, the highest enzyme activity was in the pupa stages while adults had very low GST activity (Papadopoulos et al., 2004). But there are some exceptions, for example in the two-spot lady bird (Adalia bipunctata), the highest GST activity was in both pupae and adults (Francis et al., 2002). In the honeybee, the level of GST in the development depends on the subspecies - in Apis mellifera macedonica, the GST level was at a maximum in adults (Papadopoulos et al., 2004), while in Apis mellifera carnica the highest level was at the larval stages (Farjan, 2008). Also during diapause, GST activity may vary in different ways. In overwintering larvae of Eurosta solidaginis, activity increased but in Epiblema scudderiana it decreased (Joanisse and Storey, 1996). There is no information about changes in the antioxidative system induced by artificially elongated diapause. The above points made the discussion of our results very hard.

It was observed that artificial elongation of diapause negatively influences the antioxidative system in red mason bees. It was noted, that elongation of mason bees wintering causes statistically significant decrease in TAS and also POX and GST activity (Tab. 1). These results suggest weakening of antioxidative barriers in insects emerged in the summer. The lowering of GST activity seems to be especially dangerous, since the insects do not possess selenium dependent glutathione peroxidase (GPx). Glutathione 
S-transferase plays an important role in stress physiology (Wilce and Parker, 1994). Its function is played by one of GST isoforms, which decomposes lipid peroxides using reduced glutathione as a substrate (Weinhold et al., 1990). In addition, GSTs are considered as main detoxification enzymes in insects (Chien et al., 1995; Yu, 1996), making the GSTs especially important due to the proceeding environment chemisation. If there is a lower activity of that enzyme, and also of POX, red mason bees emerged in the summer may be more susceptible on toxic compounds present in an environment. This point can explain the red mason bees' poorer fitness and shorter lifetime after emergence (Giejdasz and Wilkaniec, 1998).

It is interesting, that diapause elongation does not cause radical changes in glutathione concentration. The content of this concentration even increases slightly. The reason for this phenomenon may be limited glutathione decomposition, since it was not possible to determine the activity of one of enzymes of that compound catabolism - $\gamma$-glutamyltransferase in diapausing red mason bees (unpubl. data)

\section{CONCLUSION}

Our paper is the first one concerning an antioxidative system in red mason bees. Based on four parameters: total antioxidative ability, glutathione level and activity of peroxidase and glutathione S-transferase in $O$. rufa imago, the efficiency of defence system against ROS (that females start an active life with after cocoon emerging) could be presumed. Summing up the obtained results, it may be concluded that red mason bees emerging in nature after the wintering period (in April), start an active life equipped with efficient antioxidative barriers. Artificial elongation of the wintering period in $O$. rufa causes partial loss in the effectiveness of antioxidative systems. A lowered efficiency of ROS scavenging may lead to irreversible physiological changes in the emerging imago. Weakening of antioxidative barriers during wintering elongation and at the same time a lowering in the content of reserve substances in the imago organism, may lead to the lower survival rate of mason bees and a lowering of female reproduction efficiency (Giejdasz and Wilkaniec, 1998; Sgolastra et al., 2010; unpubl. data).

\section{ACKNOWLEDGEMXENTS}

We wish to thank Prof. dr hab. Zdzisław Wilkaniec for his continuous scientific collaboration.

\section{REFERENCES}

Bartosz G. (2003) - Druga twarz tlenu. Wydawnictwo Naukowe PWN

Bosch J., Kemp W. P. (2003) - Effect of wintering duration and temperature on survival and emergence time in males of the orchard pollinator Osmia lingaria (Hymenoptera: Megachilidae). Envir. Entomol., 32: 711-716.

Bosch J., Kemp W. P. (2004) - Effect of prewintering and wintering temperature regimes on weight loss, survival, and emergence time in the mason bee Osmia cornuta (Hymenoptera: Megachilidae). Apidologie, 35: 469-479.

Chance B., Maehly A. C. (1955) - Assay of catalases and peroxidases, in: Colowick S.P. and Kaplan N. (Ed.) Methods in Enzymology, Vol. 2. Academic Press, Inc., New York, pp: 764-775.

Chien C., Motoyama N., Dauterman W. C. (1995) - Separation of multiple forms of acidic glutathione S-transferase isozymes in a susceptible and a resistant strain of house fly, Musca domestica (L.). Arch. Insect Biochem. Physiol., 28: 397-406.

Clark A. G. (1990) - The glutathione S-transferases and resistance to insecticides: in Hayes J. D., Pickett C. B. and Mantle T. J. (Ed.) Glutathione S-transferases and Drug Resistance, Taylor and Francis, London. pp. 369-378.

Collins A. M., Williams V., Evans J. D. (2004) - Sperm storage and antioxidative enzyme expression in the honey bee,Apis mellifera. Insect Mol. Biol., 13: 141-146. 
Després L., David J. P., Gallet C. (2007) - The evolutionary ecology of insect resistance to plant chemicals. Trends Ecol. Evol., 22: 288-307.

Ellman G. L. (1959) - Tissue sulfyhydryl groups. Arch. Biochem. Biophys., 82: 70-77.

Farjan M. (2008) - Wpływ askorbinianu na metabolism cukrowy i wskaźniki antyoksydacyjne w rozwoju czerwia pszczoły miodnej (Apis mellifera carnica) nieporażonego i porażonego Varroa destructor. Doctoral thesis. University of Warmia and Mazury.

Feng Q. I., Davey K. G., Pang A. S. D., Ladd T. R., Ratnakaran A., Tomkins B., Zheng S., Palli S. (2001) - Developmental expression and stress induction of glutathione S-transferase in the spruce budworm, Christoneura fumiferana. J. Insect. Physiol., 47: 1-10.

Francis F., Haubruge E., Dierickx P. (2002) - Glutathione S-transferase izoenzymes in the two-spot ladybird, Adalia bipunctata (Coleoptera: Coccinellidae). Arch. Insect Biochem. Physiol., 49: 158-166.

Fröhlich D. R., Burris T. E., Brindley W.A. (1989) - Characterization of glutathion-S-transferase in a solitary bee, Megachile rotunda (Fab.) (Hymenoptera: Megachilidea) and inhibition by chalcones, flavones, quercetin and triphanediol. Comp. Biochem. Physiol., 94: 661-665.

Giejdasz K., Wilkaniec Z. (1998) - Effect of the activation of the bee Osmia rufa L., Megachilidae on the emerging dynamics of imagines and their survival rate. Pszczeln. Zesz. Nauk., 42: 265 - 269.

Hayaoka T., Dauterman W. C. (1982) - Induction of glutathione S-transferase by phenobarbital and pesticides in various house fly strains and its effect on toxicity. Pestic. Biochem. Physiol., 17: 113-119.

Joanisse D. R. , Storey K. B. (1996) - Oxidative stress and antioxidants in overwintering larvae of cold-hardy goldenrod gall insects. J. Exp. B., 199: 1483-1491.
Jovanovic-Galovic A., Blagojevic D., Grubor-Lajsic G., Worland R., Spasic M. B. (2004) - Role of antioxidant defenseduring different stages of preadult life cycle in European corn borer (Ostrinia nubilalis, Hübn.): diapause and metamorphosis. Arch. Insect Biochem. Physiol., 55: 79-89.

Kafel A., Bednarska K., Augustyniak M., Witas I., Szulińska E. (2003) - Activity of glutatione S-transferase in Spodoptera exigua larvae exposed to cadmium and zinc in two subsequent generations. Environ. Int., 28: 683-686.

Lee K., Berenbaum M. R. (1992) Ecological aspects of antioxidant enzymes and glutathione-S-transferases in three Papilio species. Biochem. Sys. Ecol., 3: 197-207.

Lipiński Z., Farjan M., Żółtowska K., Polaczek B. (2008) - Effects of dietary transgenic Bt maize pollen on hive worker honeybees. Polish J. of Environ. Stud., 17: 957- 961.

Maeta Y., Kurihara M. (1971) - Anatomical and histological studies on the oogenesis and oosorption of terminal oocytes within the genus Osmia. Kontyu, 39: 138-158.

Oakeshott J. G., Johnson R. M., Berenbaum M. R., Ranson H., Cristino A. S., Claudianos C. (2010) Metabolic enzymes associated with xenobiotic and chemosensory responses in Nasonia vitripennis. Insect Mol. Biol., 19: 147-163.

Papadopoulos A.I., Polemitou I., Laifi P., Yiangou A., Tananaki C. (2004) - Glutathione $S$-transferase in the insect Apis mellifera macedonica: Kinetic characteristics and effect of stress on the expression of GST isoenzymes in the adult worker bee. Comp. Biochem. Physiol., Part B: 139: 93-97.

Rice-Evans C. A., Diplock A. T., Symons M. C. R. (1991) - Techniques in Free Radical Research, Elsevier, London, New York, Tokyo.

Re R., Pellegrini N., Proteggen A., Pannala A., Yang M., Rice-Evans C. (1999) - Antioxidant activity applying and improved ABTS radical cation decolorization assay. Free Radic. Biol. Med., 26: 1231-1237. 
Sgolastra F., Bosch J., MolownyHoras R., Maini S., Kemp W. P. (2010) - Effect of temperature regime on diapause intensity in an adult-wintering Hymenopteran with obligate diapause. J. Insect Physiol., 56: 185-194.

Storey K. B. (1990) - Life in limbo: insights into the biochemical regulation of dormancy. Biochem. Cell. Biol., 68: 401-403.

Wasielewski O., Giejdasz K., Wojciechowicz T., Skrzypski M. (2011) - Ovary growth and protein levels in ovary and fat body during adult-wintering period in the red mason bee, Osmia rufa. Apidologie, 42: 749-758.

Weinhold L. C., Ahmad S., Pardini R. S. (1990) - Insect glutathione S-transferase: a predictor of allelochemical and oxidative stress. Comp. Biochem. Physiol., Part B: 95: 355-363.

Weirich G. F., Collins A. M., Williams V.P. (2002) - Antioxidant enzymes in the honey bee, Apis mellifera. Apidologie, 33: 3-14.
Whiteley G. S. W., Fuller B. J., Hobbs K. E. F. (1992) - Lipid peroxidation in liver tissue specimens stored at subzero temperatures. Cryo-Letters, 13: 83-86.

Wilce M. C., Parker M. W. (1994) - Structure and function of glutathione Stransferase. Biochem. Biophysis. Acta, 1205: $1-18$.

Wilkaniec Z. (1991) - Możliwość zastosowania Osmia rufa L. (Apoidea, Magachilidae) w zapylaniu niektórych roślin uprawnych. Rocz. AR Pozn., 229: 173-179.

Yu S. J. (1992) - Plant-allelochemical-adapted glutathione transferases in Lepidoptera, in: Mullin C.A., Scott J.G. (Ed.) Molecular Mechanisms of Insecticide Resistance, American Chemical Society, Washington DC, pp: 174-190.

$\mathrm{Yu}$ S. J. (1996) - Insect glutathione S-Transferases. Zool. Stud., 35: 9-19.

\title{
ZMIANY W UKLADZIE ANTYOKSYDACYJNYM MURARKI OGRODOWEJ (OSMIA RUFA) (HYMENOPTERA: MEGACHILIDAE) WYWOLANE SZTUCZNIE WYDLUŻONĄ DIAPAUZĄ
}

\author{
D mochowska K., Giejdasz K., \\ Fliszkiewicz M., Żóltowska K. \\ $\mathrm{S}$ t $\mathrm{r}$ e s z c z e n i e
}

Osmia rufa jako owad polilektyczny jest cennym zapylaczem roślin uprawnych. Jej użyteczność dla hodowców roślin ogranicza krótki okres lotów w środowisku naturalnym. Aby przełamać to ograniczenie wydłuża się zimowanie owadów w kokonach przetrzymując je w temperaturze $4^{\circ} \mathrm{C}$ do wymaganego przez plantatora czasu. Stwierdzono, że zabieg ten negatywnie wpływa na przeżywalność oraz czas życia murarek. Podczas sztucznego wydłużania diapauzy wzrasta współczynnik oddechowy owadów, co sugeruje, że jedną z przyczyn słabszej żywotności może być stres oksydacyjny. W tym celu zbadano wybrane elementy układu antyoksydacyjnego u $O$. rufa wygryzionych wiosną (w kwietniu) - zgodnie z ich zegarem biologicznym oraz wygryzionych latem (w lipcu) - po wydłużonej postdiapauzie. Porównano całkowity status antyoksydacyjny (TAS), zawartość glutationu (GSH) oraz aktywność peroksydazy (POX) i transferazy S-glutationowej (GST) u tych dwóch grup pszczół. Stwierdzono, że murarki wygryzione w kwietniu mają sprawniejsze bariery antyoksydacyjne niż wygryzione w lipcu. Wydłużanie postdiapauzy prowadzi do istotnego statystycznie obniżenia TAS, aktywności obu enzymów antyoksydacyjnych - POX i GST. Natomiast zmiany poziomu GSH były nieistotne. Sądzimy, że niższa sprawność układów 
antyoksydacyjnych murarek wygryzionych latem może ograniczać ich zdolności do odpowiedzi na endo- i egzogenne czynniki wywołujące stres oksydacyjny. Prezentowane wyniki są pierwszym doniesieniem dotyczącym układu antyoksydacyjnego u pszczół z rodziny Megachilidae.

Słowa kluczowe: układ antyoksydacyjny, pszczoły samotnice, murarka ogrodowa, Osmia rufa, diapauza. 